Vol. 6, n² | 2002

Varia

\title{
Theorizing in Jurassic Park: A reply to Gerd Schwerhoff
}

\section{Pieter Spierenburg}

\section{(2) OpenEdition \\ 1 Journals}

Electronic version

URL: https://journals.openedition.org/chs/423

DOI: $10.4000 /$ chs. 423

ISSN: 1663-4837

\section{Publisher}

Librairie Droz

\section{Printed version}

Date of publication: 1 December 2002

Number of pages: 127-128

ISBN: 2-600-00812-8

ISSN: 1422-0857

\section{Electronic reference}

Pieter Spierenburg, "Theorizing in Jurassic Park: A reply to Gerd Schwerhoff", Crime, Histoire \& Sociétés / Crime, History \& Societies [Online], Vol. 6, n² | 2002, Online since 19 February 2009, connection on 25 March 2022. URL: http://journals.openedition.org/chs/423 ; DOI: https://doi.org/10.4000/chs.423

This text was automatically generated on 25 March 2022.

(c) Droz 


\title{
Theorizing in Jurassic Park: A reply to Gerd Schwerhoff
}

\author{
Pieter Spierenburg
}

1 Gerd Schwerhoff has reacted to my article in the 2001/2 issue with a text almost as long as mine. Yet, my response should and can be brief. His abstract begins with the opposite answer to the question I posed: no, the combination of violence and the civilizing process does not work. However, Schwerhoff's arguments, as far as I understand them, and the historical data, suggestive statements and comments on the work of several other scholars he provides fail to add up to a convincing plea for his case. Largely, I wish to leave this to the judgment of the readers themselves.

2 The methodological discussion concerning homicide rates, for example, will no doubt continue among the specialists (see also Monkkonen's contribution to the 2001/2 issue). Let me just remark that the work of the Belgian historian Vanhemelryck, one of Schwerhoff's sources, should not be taken as a serious contribution to scholarship. More important is it to take note of Schwerhoff's conclusions from the homicide rates he presents: (1) «the level of violence was relatively high in the late Middle Ages» and (2) «the level of violence decreased from the 16th to the 18th centuries». Indeed!

3 Regarding Elias' theory of civilization, some misunderstandings prove tenacious. The term «monopoly of power», for example, is a contradiction in terms. Elias emphasized time and again that power is an aspect of all social relationships and that, although power relations are usually unequal, they are always two-sided. Hence, «monopolization of power» is simply an impossibility (see my forthcoming article Foucault and Elias). When Schwerhoff does get it right with the theory of civilization, his strategy is to propose another reading. Thus, he admits that Elias (and I) consider violence [and other forms of relatively impulsive behavior] as a social habit which has to be learned; he goes on to suggest, however, that Elias did not really mean this. Neither do Elias and the scholars who, like me, adopt his approach speak of indepent and dependent variables, only of interdependent developments. Finally, although Elias considered each person's «affect economy» as a totality, he clearly recognized that in 
certain periods and/or among certain social groups, the control of one or the other type of behavior received special emphasis.

4 Several specific themes Schwerhoff introduces fail to sustain his overall argument. Discussing social control, for example, he points at long-term changes in the social appreciation of violence - evidence which rather supports my view. When it comes to questions of definition, he says we should also speak of «verbal violence». I do not, but in any case, the inclusion of insults and the like into the category of violence would significantly increase the total incidence of violence during the early phases of the long-term development which I and many others postulate. Also, contrary to what Schwerhoff suggests, I have always insisted that rape belongs to the category of violence, rather than morals offenses. A detailed discussion of the definition of violence would take to much space, but Schwerhoff's claim «whether the protagonists fought with sharp words or sharp knives does not make a difference» is unacceptable. For one thing, it did make a difference to the Amsterdam court around 1700, which largely ignored the first but punished the second severely.

5 As to changes in the character and context of violence, I maintain that these, too, can be studied over the long term. Although Schwerhoff appears to reject the «axes» I proposed, he actually critizes an author who takes issue with me on this point! The article in question, by Eva Lacour, was published after I had written mine; I agree with Schwerhoff that it has highly problematic categorizations. Far from showing what is wrong with the notion of axes of violence, Schwerhoff chides me for not having suspended my agreement with the theory of civilization until further evidence on the character and context of violence is forthcoming. Finally, my key argument is left undiscussed: adherence to ritual is compatible with impulsiveness and hence with a relatively low level of emotional control. Schwerhoff completely refrains from even an attempt at a counter-argument.

6 Ultimately, he rejects a historical-sociological approach, calling the theory of civilization «the last theoretical dinosaur of its kind». That kind would include Durkheim, favored as a theorist by Thome in the 2001/2 issue. Thus, Schwerhoff refuses to accept that meaningful insights can be derived from the comparison of human behavior in contexts widely diverging in space and over time. Many scholars, on the other hand, consider this a fruitful enterprise. The prediction that theories about society, like the dinosaurs, will become extinct is a specimen of wishful thinking.

\section{AUTHOR}

\section{PIETER SPIERENBURG}

Faculteit Historische en Kunstwetenschappen, Erasmus Universiteit, Rotterdam (Pays-Bas), spierenburg@fhk.eur.nl 